\title{
EXPERIMENTAL STUDY ON PROPERTIES OF CONCRETE USING GROUND GRANULATED BLAST FURNACE SLAG AND COPPER SLAG AS A PARTIAL REPLACEMENT FOR CEMENT AND FINE AGGREGATE
}

\author{
Divya Krishnan K.," ${ }^{1,}$ P.T.Ravichandran ${ }^{1}$ and V. K. Gandhimathi ${ }^{2}$ \\ ${ }^{1}$ Department of Civil Engineering, SRM University, Kattankulathur-603203, Tamil Nadu, India. \\ ${ }^{2}$ Public Works Department, Chepauk, Chennai-600005, Tamil Nadu, India \\ *E-mail : er.divyakrishnan@gmail.com
}

\begin{abstract}
Past few decades the consumption of Concrete become very prominent and the demand for concrete is increasing rapidly due to rapid growth in the construction industry. As a result, the concrete industry is facing with a declining availability of natural resources used as a raw and construction materials. Cement is the widely used binding material in concrete and it's over-exploitation of cement has led to various harmful consequences. Hence an alternative material for cement is required and it will lead to the decrease in the production of $\mathrm{CO}_{2}$. Similarly, the availability of river sand is also less and it leads to the need of alternative of fine aggregate with better properties which will eliminate the economic problem. In this study, conventional concrete M30 grade concrete mix was designed with Ground Granulated Blast Furnace Slag (GGBS) to cement and Copper slag (CS) to fine aggregate as partial replacement. The Compressive strength, split tensile and flexural strength variation for concrete mix with GGBS $(0 \%, 10 \%, 20 \%$ and $30 \%)$ and fine aggregate with varying percentage of Copper slag $(0 \%, 10 \%, 20 \%, 30 \%$ and $40 \%$ ) are determined at various curing period such as 7 and 28 days. From the experimental test results, it is observed that the $28^{\text {th }}$ day compressive strength, the split tensile strength and flexural strength of concrete up to $30 \%$ partial replacement of GGBS for cement along with $30 \%$ copper slag as fine aggregate give almost better results while compared with conventional concrete strength. Thus the alternate material for fine aggregate and cement by the partial replacement with Copper slag and GBBS, improve the strength characteristic and it safeguards the environment by utilizing waste properly and reduces its disposal problems.
\end{abstract}

Keywords: Copper Slag, GGBS, Compressive strength, Tensile strength

(c) RASĀYAN. All rights reserved

\section{INTRODUCTION}

For the stable and acceptable society, the use, as well as the transformation from the conventional procedures, demands more and it was mainly aiming towards the sustainability in all aspects. Among many challenging problems all over the world, the use of conventional construction materials in construction industries aims major issue. Thus, it demands the use of available materials in a proper way by reducing the difficulties that affecting the environment adversely. Based on this consideration, the concrete technologies have to advance with the consumption of many waste products in concrete, by reducing the causes of environmental pollution due to its large disposal. Many studies, on alternative binders such as lime ${ }^{1-3}$, fly ash ${ }^{4-7}$, volcanic ash ${ }^{8,9}$, Nano Silica ${ }^{10}$, Silica fume ${ }^{11}$ etc. had been carried out on the use of binding agents in civil engineering field. In concrete industry the use of alternate binding agent as the partial replacement for cement are becoming an advancing method and economically satisfactory technique in the enhancement of mechanical properties in concrete.

For the recent years, researchers are concentrating on the aggregate replacement ${ }^{12-15}$ studies in concrete better quality mixes. Taking this into theaccount, this study mainly concentrates on the effect of GGBS as binding material in concrete as well as a combination of GGBS with cement and Copper Slag (CS) along with aggregate for a workable high-quality mix. By the use of GGBS and CS in concrete can reduces 
environmental issues related to its disposal and use of GGBS as binding material lowers the liberation of heat by consumption of large quantity of cement in construction activities.

\section{EXPERIMENTAL}

Ordinary Portland Cement (OPC) of grade 43, natural sand less than $4.75 \mathrm{~mm}$ size and coarse aggregate up to size range $20 \mathrm{~mm}$ are used in this study. Both the fine and coarse aggregates used met the IS gradation ${ }^{16}$ requirements. Along with these materials, cement and fine aggregate are partially replaced with Ground Granulated Blast furnace Slag (GGBS) and Copper Slag (CS) respectively. GGBS is a slag obtained as aby-product of iron and steel manufacturing from a blast furnace. CS is also an industrial byproduct material produced from the copper extraction process. For this study M30 grade concrete mix was designed with partial replacement of cement with GGBS $(0 \%, 10 \%, 20 \%$ and 30\%) and fine aggregate with CS $(0 \%, 10 \%, 20 \%, 30 \%$ and $40 \%)$. Once the casting of all the concrete specimens are over, it were demoulded after 24 hours, and placed in the curing tank till the period of testing time. For each combination of mixes three specimens were prepared and tested for the precise values. The mechanical properties of each concrete mixture was evaluated with respect to compressive strength, splitting tensile strength and flexural strength of hardened concrete ${ }^{17,18}$ at curing periods of 7 and 28 days.

\section{Compressive strength}

\section{RESULTS AND DISCUSSIONS}

Compressive strength test was carried out with different percentage of GGBS as partial replacement of cement in concrete specimens and the strength results are measured at 7 and 28 days are shown in Table1. It revealed that the compressive strength of GGBS blended concretes was decreases with the increase in the addition of GGBS. With 30\% GGBS for cement replacement, showed that the compressive strength of concrete was decreased to $32 \mathrm{~N} / \mathrm{mm}^{2}$ from $37 \mathrm{~N} / \mathrm{mm}^{2}$ value, so that rate of decrease in compressive strength is less and it confirms the use of GGBS as a binding material along with cement.

\section{Effect of GGBS and CS on compressive strength of concrete}

The effect of GGBS as binder material and CS as fine aggregate concrete mixes are also studied and the results of combination mixes are tabulated in Table-2. From the results, it was clear that strength increases substantially compared to concrete with GGBS alone. It is due to the contributions from pozzolanic reactions of CS as well as GGBS.

The variations in 28th day compressive strength of GGBS and CS mixed concrete are shown in Fig.1.The result at 28 days of concrete indicated a significant improvement in strength compared with the control mix and the compressive strength value obtained for 30\% GGBS with $30 \%$ CS shows the maximum value of $53 \mathrm{~N} / \mathrm{mm}^{2}$.

Table - 1: Compressive strength results of GGBS mixed concrete at 7 and 28 days of curing.

\begin{tabular}{c|c|c|c}
\hline \multirow{2}{*}{ GGBS\% } & \multirow{2}{*}{ Mix Designation } & \multicolumn{2}{|c}{ Compressive Strength, N/mm } \\
\cline { 3 - 4 } & & 7 Days & 28 Days \\
\hline $0 \%$ & M1 & 27 & 37 \\
\hline $10 \%$ & M2 & 28 & 36 \\
\hline $20 \%$ & M7 & 29 & 34 \\
\hline $30 \%$ & M12 & 31 & 32 \\
\hline
\end{tabular}

\section{Split Tensile Strength}

The split tensile strength tests were carried out on the $150 \mathrm{~mm}$ diameter and $300 \mathrm{~mm}$ height cylindrical specimens, which have prepared with GGBS and CS along with GGBS combinations of concrete mixes. Table-3 shows that the variations in split tensile strength values obtained at different curing periods of GGBS concrete specimens. The split tensile strength value shows an increase in strength of $4.29 \mathrm{~N} / \mathrm{mm}^{2}$ from conventional concrete strength value of $3.6 \mathrm{~N} / \mathrm{mm}^{2}$. 


\section{Effect of GGBS and CS on split tensile strength of concrete}

Split tensile strength on concrete mixes with GGBS along with cement and CS with fine aggregate was determined and test results are listed in Table- 4 . The values indicate an increase in strength than the control mix concrete due to increase in weight of CS content. At the curing period of 28 days, increase in GGBS and CS combinations results in an improvement of split tensile strength of $4.79 \mathrm{~N} / \mathrm{mm}^{2}$ from the conventional concrete value of $3.6 \mathrm{~N} / \mathrm{mm}^{2}$. This highest split tensile value was obtained with $30 \%$ GGBS and $30 \% \mathrm{CS}$ concrete and the rate of increase was around $33 \%$ compared with conventional concrete.

Table - 2: Compressive strength results of GGBS and CS mixed concrete

\begin{tabular}{|c|c|c|c|c|}
\hline \multirow{2}{*}{ GGBS $\%$} & \multirow{2}{*}{$\begin{array}{l}\text { Copper } \\
\text { Slag, \% }\end{array}$} & \multirow{2}{*}{ Mix Designation } & \multicolumn{2}{|c|}{ Compressive Strength, $\mathrm{N} / \mathrm{mm}^{2}$} \\
\hline & & & 7 Days & 28 Days \\
\hline $0 \%$ & $0 \%$ & M1 & 26 & 37 \\
\hline \multirow{5}{*}{$10 \%$} & $0 \%$ & M2 & 27 & 36 \\
\hline & $10 \%$ & M3 & 28 & 38 \\
\hline & $20 \%$ & M4 & 30 & 41 \\
\hline & $30 \%$ & M5 & 33 & 44 \\
\hline & $40 \%$ & M6 & 33 & 45 \\
\hline \multirow{5}{*}{$20 \%$} & $0 \%$ & M7 & 25 & 34 \\
\hline & $10 \%$ & M8 & 33 & 45 \\
\hline & $20 \%$ & M9 & 34 & 46 \\
\hline & $30 \%$ & M10 & 36 & 49 \\
\hline & $40 \%$ & M11 & 38 & 51 \\
\hline \multirow{5}{*}{$30 \%$} & $0 \%$ & M12 & 24 & 32 \\
\hline & $10 \%$ & M13 & 34 & 46 \\
\hline & $20 \%$ & M14 & 37 & 50 \\
\hline & $30 \%$ & M15 & 39 & 53 \\
\hline & $40 \%$ & M16 & 38 & 52 \\
\hline
\end{tabular}

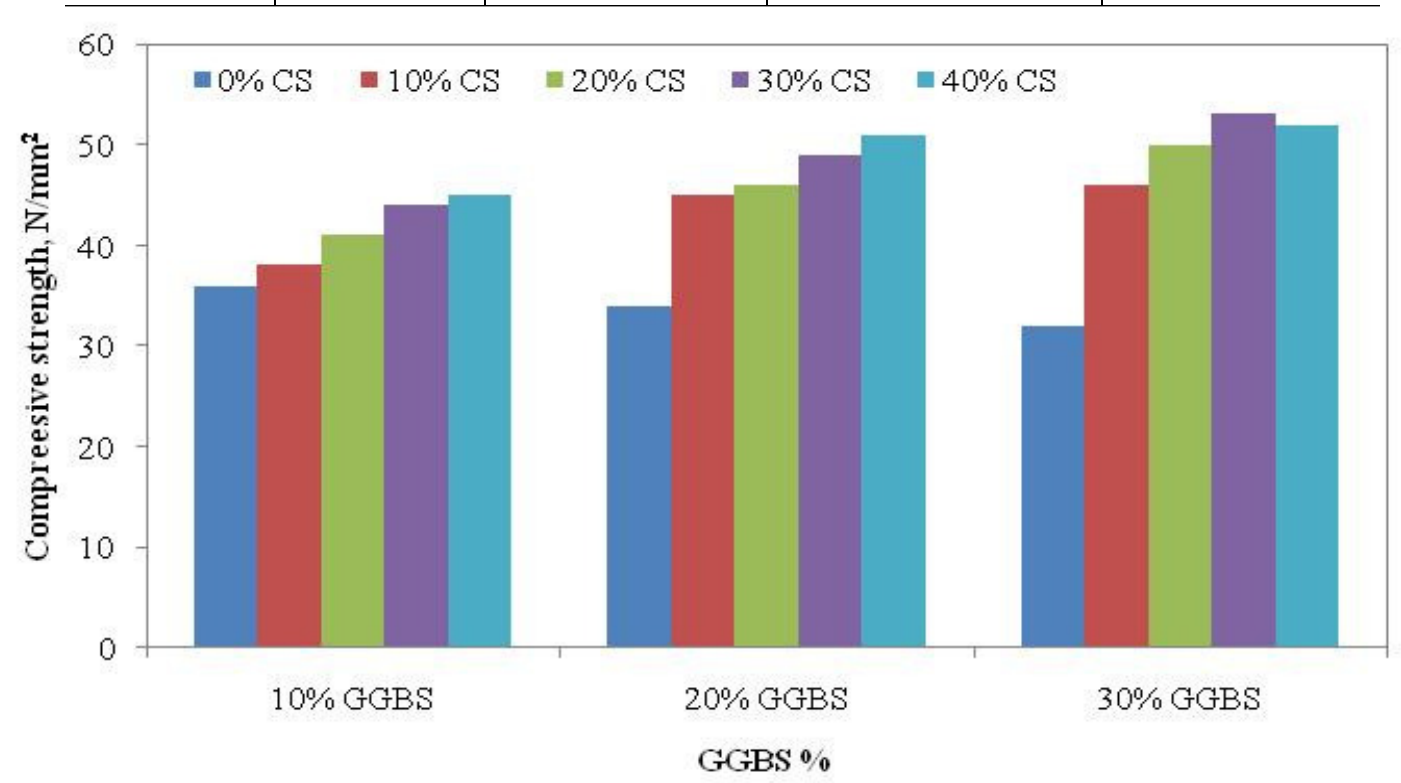

\section{Flexural Strength}

Fig.-1: Effect of GGBS and CS percentages on $28^{\text {th }}$ day compressive strength

Flexural strength of concrete mixtures was determined at the ages of 7 and 28 days concrete on the beams of size $100 \times 100 \times 500 \mathrm{~mm}$ prepared as per Indian standard and the results of GGBS mixed concrete are given in Table-5. At 28 days curing age, the flexural strength of $30 \%$ GGBS added concrete shows the strength of $4.4 \mathrm{~N} / \mathrm{mm}^{2}$ and it was more than the conventional concrete strength value. 
RASĀYAN J. Chem.

Vol. 10 | No. 2 |600-605 | April - June | 2017

Table - 3: Split tensile strength results of GGBS mixed concrete at 7 and 28 days of curing

\begin{tabular}{c|c|c|c}
\hline \multirow{2}{*}{ GGBS $\%$} & \multirow{2}{*}{ Mix Designation } & \multicolumn{2}{|c}{ Split tensile Strength, N/mm ${ }^{2}$} \\
\cline { 3 - 4 } & & 7 Days & 28 Days \\
\hline $0 \%$ & M1 & 2.66 & 3.6 \\
\hline $10 \%$ & M2 & 2.75 & 3.72 \\
\hline $20 \%$ & M7 & 2.88 & 3.99 \\
\hline $30 \%$ & M12 & 2.91 & 4.29 \\
\hline
\end{tabular}

Table - 4: Split tensile strength results of GGBS and CS mixed concrete

\begin{tabular}{|c|c|c|c|c|}
\hline \multirow[b]{2}{*}{ GGBS, $\%$} & \multirow{2}{*}{$\begin{array}{c}\text { Copper Slag, } \\
\%\end{array}$} & \multirow{2}{*}{ Mix Designation } & \multicolumn{2}{|c|}{ Split tensile Strength, $\mathrm{N} / \mathrm{mm}^{2}$} \\
\hline & & & 7 Days & 28 Days \\
\hline $0 \%$ & $0 \%$ & M1 & 2.66 & 3.6 \\
\hline \multirow{5}{*}{$10 \%$} & $0 \%$ & M2 & 2.75 & 3.72 \\
\hline & $10 \%$ & M3 & 2.83 & 3.83 \\
\hline & $20 \%$ & M4 & 2.97 & 4.01 \\
\hline & $30 \%$ & M5 & 3.18 & 4.3 \\
\hline & $40 \%$ & M6 & 3.46 & 4.67 \\
\hline \multirow{5}{*}{$20 \%$} & $0 \%$ & M7 & 2.95 & 3.99 \\
\hline & $10 \%$ & M8 & 3.05 & 4.12 \\
\hline & $20 \%$ & M9 & 3.17 & 4.29 \\
\hline & $30 \%$ & M10 & 3.26 & 4.41 \\
\hline & $40 \%$ & M11 & 3.37 & 4.56 \\
\hline \multirow{5}{*}{$30 \%$} & $0 \%$ & M12 & 3.17 & 4.29 \\
\hline & $10 \%$ & M13 & 3.23 & 4.37 \\
\hline & $20 \%$ & M14 & 3.41 & 4.61 \\
\hline & $30 \%$ & M15 & 3.54 & 4.79 \\
\hline & $40 \%$ & M16 & 3.34 & 4.52 \\
\hline
\end{tabular}

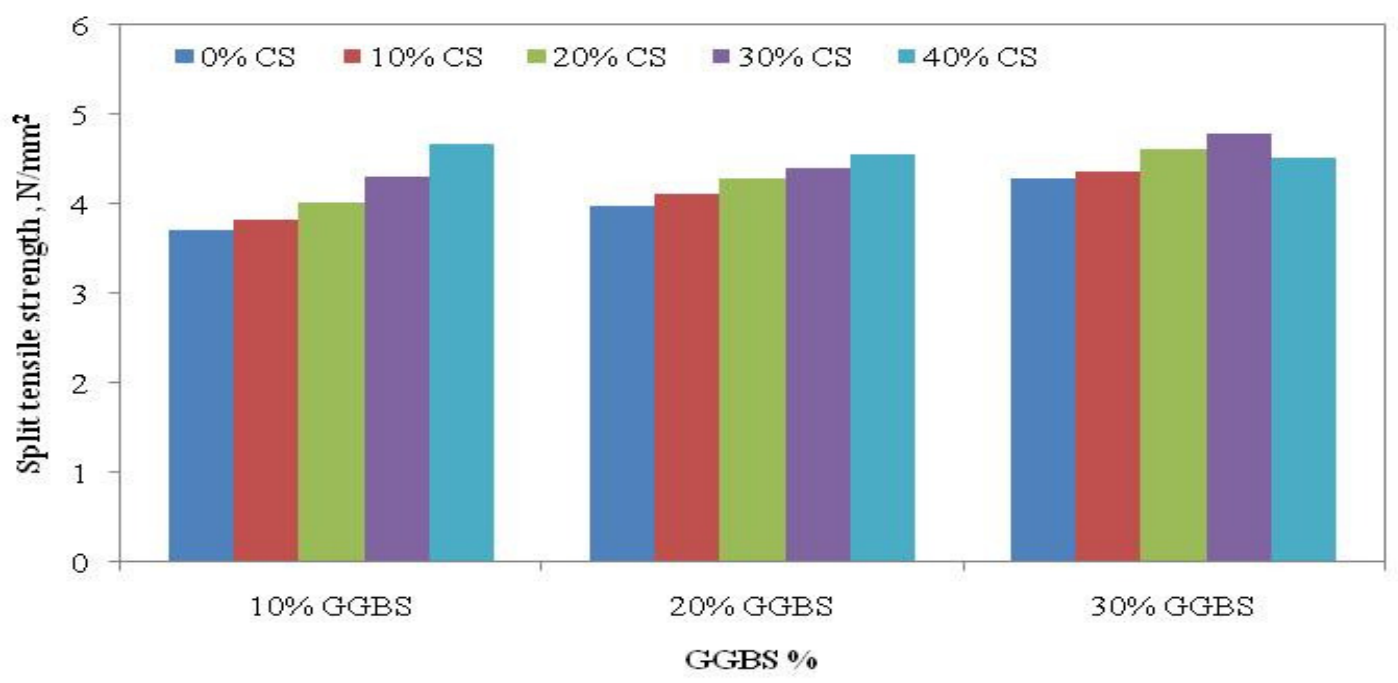

Fig.-2: Effect of GGBS and CS percentages on $28^{\text {th }}$ day split tensile strength

Table - 5: Flexural strength results of GGBS mixed concrete at 7 and 28 days of curing.

\begin{tabular}{c|c|c|c}
\hline \multirow{2}{*}{ GGBS, \% } & \multirow{2}{*}{ Mix Designation } & \multicolumn{2}{|c}{ Flexural Strength, N/mm $\mathrm{mm}^{2}$} \\
\cline { 3 - 4 } & & 7 Days & 28 Days \\
\hline $0 \%$ & M1 & 3.08 & 4.16 \\
\hline $10 \%$ & M2 & 3.12 & 4.26 \\
\hline
\end{tabular}


RASĀYAN J. Chem.

Vol. 10 | No. 2 |600-605 | April - June | 2017

\begin{tabular}{c|c|c|c}
\hline $20 \%$ & M7 & 3.03 & 4.31 \\
\hline $30 \%$ & M12 & 2.95 & 4.40 \\
\hline
\end{tabular}

\section{Effect of GGBS and CS on flexural strength of concrete}

Similar to compression and split tensile strength tests, flexural strength tests were also conducted on concrete specimens prepared with GGBS and CS. The results obtained for the various mix combinations are shown in Table-6. It was observed that for 30\% GGBS with 30\% CS replacement concrete specimen gives the considerable improvement in strength. Figure-3 presenting the variation in 28-day strength achievement of various proportions of concrete mixes.

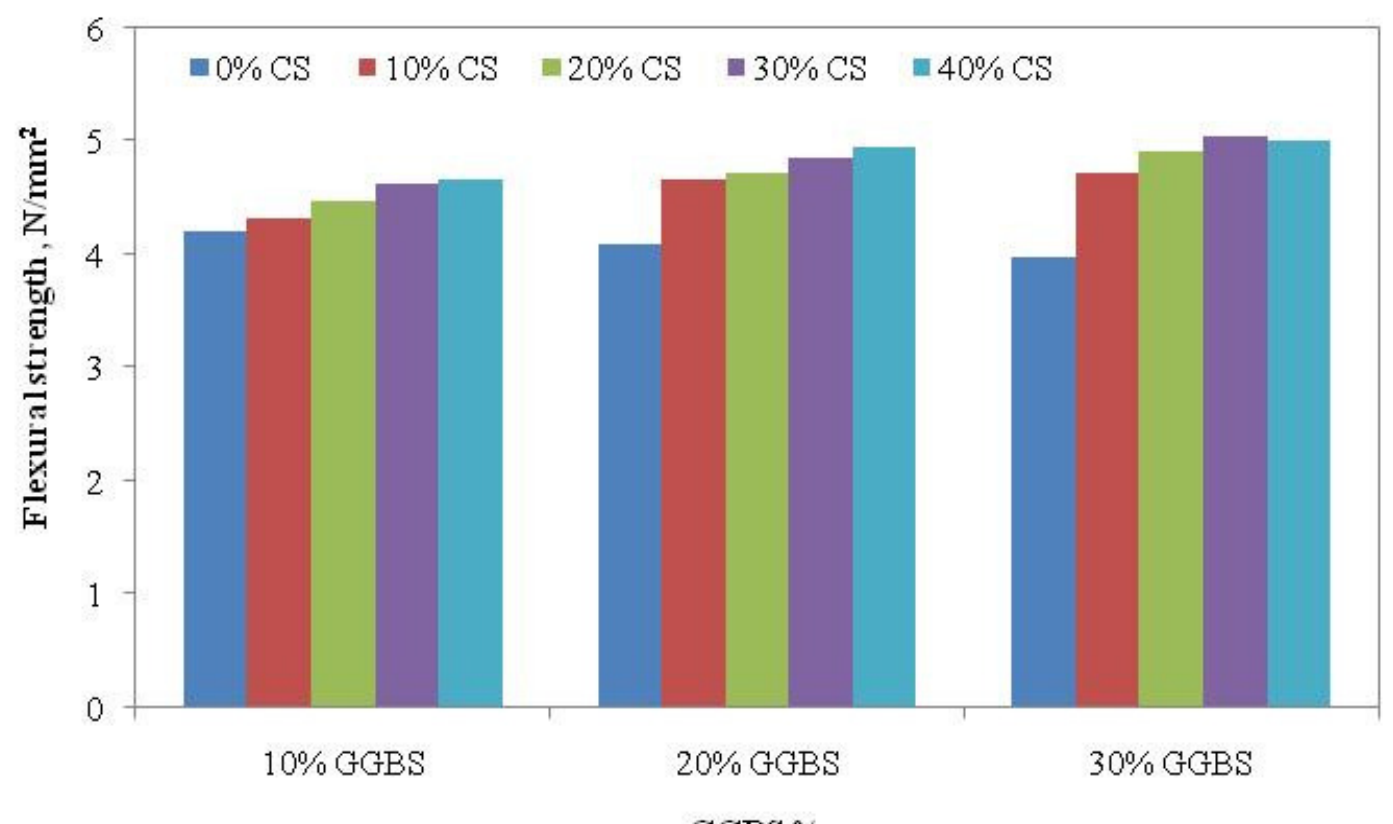

Fig.-3: Effect of GGBS and CS percentages on $28^{\text {th }}$ day flexural strength

Table - 6: Flexural strength results of GGBS and CS mixed concrete

\begin{tabular}{|c|c|c|c|c|}
\hline \multirow{2}{*}{ GGBS $\%$} & \multirow{2}{*}{ Copper Slag \% } & \multirow{2}{*}{$\begin{array}{c}\text { Mix } \\
\text { Designation }\end{array}$} & \multicolumn{2}{|c|}{ Flexural Strength, $\mathrm{N} / \mathrm{mm}^{2}$} \\
\hline & & & 7 Days & 28 Days \\
\hline $0 \%$ & $0 \%$ & M1 & 3.08 & 4.16 \\
\hline \multirow{5}{*}{$10 \%$} & $0 \%$ & M2 & 3.12 & 4.26 \\
\hline & $10 \%$ & M3 & 3.19 & 4.32 \\
\hline & $20 \%$ & M4 & 3.31 & 4.47 \\
\hline & $30 \%$ & M5 & 3.42 & 4.62 \\
\hline & $40 \%$ & M6 & 3.46 & 4.67 \\
\hline \multirow{5}{*}{$20 \%$} & $0 \%$ & M7 & 3.03 & 4.31 \\
\hline & $10 \%$ & M8 & 3.46 & 4.67 \\
\hline & $20 \%$ & M9 & 3.49 & 4.72 \\
\hline & $30 \%$ & M10 & 3.60 & 4.86 \\
\hline & $40 \%$ & M11 & 3.66 & 4.95 \\
\hline \multirow{5}{*}{$30 \%$} & $0 \%$ & M12 & 2.95 & 4.40 \\
\hline & $10 \%$ & M13 & 3.49 & 4.72 \\
\hline & $20 \%$ & M14 & 3.63 & 4.91 \\
\hline & $30 \%$ & M15 & 3.73 & 5.04 \\
\hline & $40 \%$ & M16 & 3.70 & 5.00 \\
\hline
\end{tabular}




\section{CONCLUSION}

The compressive strength of the specimen containing 30\% GGBS as a replacement for cement gives a reduction in strength value and it is lesser compared to conventional concrete strength value, and thus it confirms the use of GGBS as a binding material along with cement.

From the split tensile strength results of GGBS mixed concrete, the 28-day result shows an increase in strength of $4.29 \mathrm{~N} / \mathrm{mm}^{2}$ from conventional concrete strength value of $3.6 \mathrm{~N} / \mathrm{mm}^{2}$. Concrete mixes with GGBS along with cement and CS with fine aggregate was indicated an increase in strength of $4.79 \mathrm{~N} / \mathrm{mm}^{2}$ from the conventional concrete value of $3.6 \mathrm{~N} / \mathrm{mm}^{2}$ with $30 \%$ GGBS and $30 \%$ CS concrete.

The flexural strength of $30 \%$ GGBS mixed concrete shows a strength value of $4.4 \mathrm{~N} / \mathrm{mm}^{2}$ which is more than the conventional concrete strength and the concrete with combination of GGBS and CS also gaves the considerable improvement in strength.

The results showed that the strength properties of concrete were acceptable it was worth in utilizing GGBS and CS in concrete as a partial replacement for cement and aggregate and also it proves as a good technique for solving an environmental issue caused by its disposal.

\section{REFERENCES}

1. Tarun R. Naik, Shiw S. Singh and Mohammad M. Hossain, Construction and Building Materials, 9 (4), 195(1995).

2. K. Celik, M.D. Jackson, M. Mancio, C. Meral, A.-H. Emwas, P.K. Mehta, P.J.M. Monteiro, Cement and Concrete Composites, 45, 136(2014).

3. Federica Lollini, Elena Redaelli, Luca Bertolini, Cement and Concrete Composites, 46, 32(2014).

4. Rafat Siddique, Cement and Concrete Research, 34, 487(2004).

5. Aman Jatale, Kartikey Tiwari, Sahil Khandelwal, Journal of Mechanical and Civil Engineering, 5(4), 34 (2013).

6. P. T. Ravichandran, Divya Krishnan K, V. Janani, R. Annadurai, Manisha Gunturi, , International Journal of Chem Tech Research, 7(2), 622 (2015).

7. L. Krishnaraj, Yeddula Bharath Simha Reddy, N. Madhusudhan and P.T. Ravichandran, Rasayan Journal of Chemistry, 10(2), 423 (2017).

8. K. M. A. Hossain, M. Lachemi, Cement and Concrete Research, 37, 759(2007).

9. Mohammed Seddik Meddah, Construction and Building Materials, 79, 73(2015).

10. Mahboubeh Zahedi, Ali Akbar Ramezanianpour, Amir Mohammad Ramezanianpour, Construction and Building Materials, 78, 354 (2015).

11. N. Parthasarathi, M. Prakash, K. S. Satyanarayanan, Rasayan Journal of Chemistry, 10(2), 442 (2017).

12. Arul Arulrajah, Alireza Mohammadinia, Suksun Horpibulsuk, Wisanukorn Samingthong, Construction and Building Materials, 127, 743(2016).

13. F. Pacheco-Torgal, Yining Ding, Said Jalali, Construction and Building Materials, 30, 714(2012).

14. C Sudha, Ajesh K Kottuppillil, P.T. Ravichandran, Divya Krishnan K, Indian Journal of Science and Technology, 9(34), 1(2016).

15. S.C. Kou, C.S. Poon, Cement and Concrete Composites, 31, 622 (2009).

16. IS: 383 -1970, Bureau of Indian Standards, New Delhi.

17. IS: 516 - 1959, Bureau of Indian Standards, New Delhi.

18. IS: 5816 - 1999, Bureau of Indian Standards, New Delhi.

[RJC-1677/2017] 